\title{
Improving Competitive Tourism with Branding Strategy
}

\author{
Titus Indrajaya \\ Management Department \\ University of Respati Indonesia \\ Jakarta, Indonesia \\ titus@urindo.ac.id
}

\begin{abstract}
As a member of G20 country, group of countries with large economy, Indonesia should has a strong national branding and needs to raise the competitiveness in the international level. Indonesia has "Wonderful Indonesia" that is able to sell the beauty of marine tourism, cultural uniqueness and diversity, which could potentially bring in foreign tourists. Department of Culture and Tourism Banten Province supports the development of the leading tourism destinations in eight regencies / cities as an effort to increase economic growth. Many region's potential spots such as Tanjung Lesung and Carita Beach in Pandeglang. From the 18 tourist areas in Banten spread over eight districts / cities with a number of tourist destinations more than 500 spots, has a unique advantage in each area that could be improved and developed. The method used is a literature study with a descriptive exploratory approach. This study is a qualitative research that is based on secondary data. The results of this study to determine: (1) tourism marketing strategy in Banten Province in developing branding to increase the competitiveness of tourism (2) the factors inhibiting and supporting the implementation effort in developing branding in Banten Province.
\end{abstract}

Keywords-component; formatting; style; styling; insert

\section{INTRODUCTION}

Travel and tourism is one industry that is now global as well and is widely regarded as one of the fastest growing industries in the world, if it can not be said to be the fastest growing industry. Almost all countries now getting ready to attract as many as possible of the traveler and tourism Indonesia which is an island country that has a lot of tourism potential of the plume, not only will the natural wealth that has been formed by itself, but also the wealth of Suber human in it that shows how rich our culture, ranging from ethnicity, race, religion, and language area. Potential areas like a product or service is packaged and given brand that has a characteristic that distinguishes the potential of other areas.

Indonesia as a G20 member countries, the group of countries with large economies should has a strong nation branding and needs to raise the competitiveness in the International level. Some of the other Asean countries such as Malaysia, Singapore have been able to make a strong Nation Branding and able to bring foreign tourists. Malaysia with a "Truly Asia" and Singapore "Your Singapore" has a unique positioning and able to sell their country. Indonesia with
"Wonderful Indonesia" hopely able to sell the beauty of marine tourism, cultural uniqueness and diversity of other potentially bring in foreign tourists.

Based on the latest data issued by the Pacific Asia Travel Association (PATA) - Asia Pacific Visitor Arrival Forecasts 2014-2018 - Thailand is the country most visited by foreign tourists. In 2013, Thailand receive international tourist arrivals of 26.5 million. Then followed by Malaysia at number 26.3 million. Third is Singapore with figures of 15.6 million visits.

What about Indonesia? Indonesia ranks fourth with 8.3 million figure. Vietnam is in the next sequence with the figure of 7.4 million visits. Then, with the number of visits the Philippines and Cambodia 4.4 million of 4.3 million. In the final position is with the number of visits Laos and Myanmar 3,9 million 800 thousand visits.

The task to be executed a brand manager is usually associated with market analysis, targeting, positioning strategy, performance analysis and adjustment strategy, identifying new product needs and coordination of marketing activities (Cravens \& Piercy, 2006)

Indonesia as a country that has a lot of natural and cultural wealth also not to be outdone to offer tourism potential. Based on Law No. 21 of 1999 which was then revised by Law Number 32 Year 2004 regarding the regulatory regions containing about regional autonomy. According to these regulations, many areas began to explore the region's potentials.

Department of Culture and Tourism Banten encourages the development of the leading tourism destinations in eight regencies / cities in a bid to spark economic growth. Lots of potential in the regions as an example of Pandeglang Tanjung Lesung and Carita Beach. With the 18 tourist areas in Banten spreads over eight districts / cities with a number of tourist destinations more than 500 destinations, has a unique advantage in each area that could be improved and developed.

Banten Province as one of the provinces which has diverse tourism potential and cultural uniqueness should be able to bring greater foreign tourists. That's why nation branding strong as differentiation is an effort that can be done to boost the tourism potential. 
According to Kotler and Keller (2009, h.42), a brand is a perceptual entity rooted in reality, but it reflects the perceptions and even thoughts and feelings. Brand personality is a specific mix of human nature possessed by a product or service. Research shows that the brand has a personality to be preferred by consumers because people tend to choose a brand that has a personality that matches their personality.

In connection with these problems, the problem in this research are:

1. How does tourism marketing strategy in Banten Province to improve the competitiveness of tourism?

2. How inhibitor and supporters in an effort to build brand image branding in Banten province in order to attract tourist?

The purpose of this research to determine: (1) tourism marketing strategy in Banten province in building branding to enhance the competitiveness of tourism (2) the factors inhibiting and supporting the implementation effort in building branding in Banten Province. The method used was a literature study with a descriptive exploratory approach. This study is a qualitative research which is based on secondary data. Relevant sources used in strategic alliances and business partnerships.

\section{DISCUSSION}

\section{A. Banten Province}

One of the provinces in Indonesia who continue to develop tourism in the provinces of Banten. Banten is located between the islands of Sumatra, Java and Jakarta-west, with an area of $8.651 .20 \mathrm{~km} 2$ (Act No. 23 of 2000), the division of administrative regions 4 and 4 Cities, 155 Districts, 133 Villages and 1238 villages few outside the city to the west there is the famous volcano Krakatao volcano that last erupted in 1883 large.

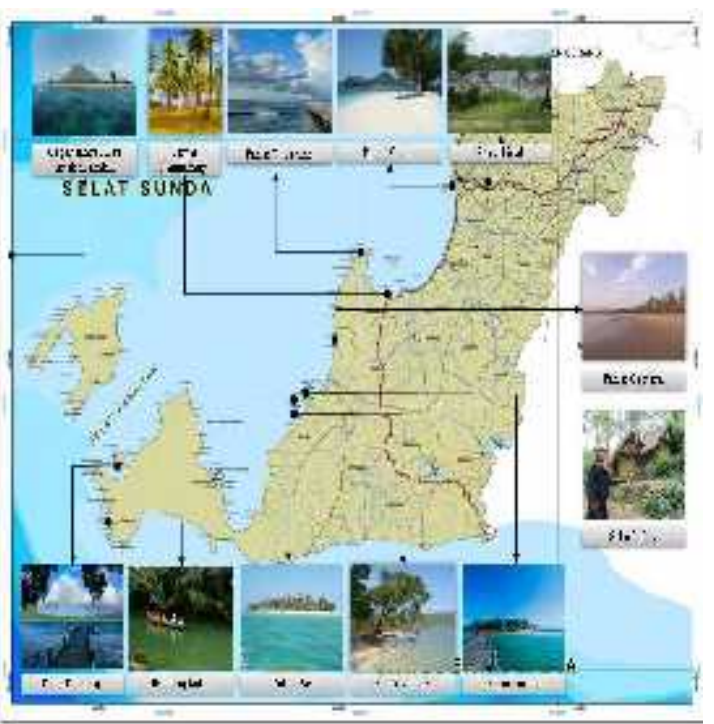

Fig. 1. Map of Banten Province
Ujung Kulon National Park is one of the world's natural conservation area declared by UNESCO (world heritage site).

Traditional Baduy community located in Lebak region, living in an area of approximately 5101 hectares. The tribe is divided into two, namely Baduy outside and inside. They live with harmony with nature and avoid life outside the modern world. They live with simplicity.

Department of Culture and Tourism Banten offers the concept of integrated tourism destination, namely Mount Krakatau, Rhino (Rhinoceros Ujung Kulon) and Tanjung Lesung by the term 'Triangle' (triangle) Banten tourism, in order to increase tourist visits to Banten.

Level of tourist arrivals in Banten throughout 2015 to reach 14 million people, but the figure is considered still lags behind other regions in Java. Moreover, Soekarno-Hatta International Airport located in the Banten Province.

TABLE I. TABLE TOURIST ARRIVALS

\begin{tabular}{|c|c|c|c|c|c|}
\hline \multirow[b]{2}{*}{ No } & \multirow[b]{2}{*}{ Instenst: } & \multicolumn{2}{|c|}{ Tahun 2014} & \multicolumn{2}{|c|}{ Tahen 2015} \\
\hline & & Wisrus & Wisman & Wistus & Wsman \\
\hline 1 & Disparporz Sab. Sararg & 9.236 .300 & 3.583 & 10063.535 & - \\
\hline 2 & Disporabudpar vad, Far weares & 51.461 & 24.153 & $5\llcorner A 6]$ & 29.163 \\
\hline 3 & Disparekrat kna Taverary & 237.263 & 27.697 & 237.263 & $27.69 ?$ \\
\hline 4 & Distucparkota C eqor & 35.867 & 35,618 & 103.667 & 39.508 \\
\hline 5 & Discoragartuc uoto Serane & $29 ! 119$ & 6.655 & 305.473 & 490 \\
\hline$E$ & Eta $p$ estarian cagr buta, & 199.100 & 148 & 371,890 & 1947 \\
\hline 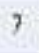 & Disporaper Gab. labst & 54.724 & 193 & 54.724 & 193 \\
\hline 8 & Tenàkes mul U/ung Kuloo & 11.223 & 1.206 & 13,316 & 834 \\
\hline$y$ & Disparวore Gab. Pantesjang & 3.146 .761 & 4.139 & $3 . .46 .762$ & 41.19 \\
\hline \multirow[t]{2}{*}{10} & Bantor Etdpar Tanged & • & - & 255.953 & 23.882 \\
\hline & & $13,66,0.813$ & 108.712 & 14.563 .593 & 127,943 \\
\hline
\end{tabular}

Tourism has not played yet a major role in the economy of Banten. But it develops better every year. It can be prooved from the growth in the new 20133.89 percent to 11.8 percent in 2014. Based on data from the Central Statistics Agency (BPS) Banten published in Economic Studies and Regional Finance (KEKR) Bank Indonesia (BI) Banten mention, so far domestic and foreign travelers coming to Banten only $7 \%$ of the total travelers who come to the island of Java. Since the beginning of this year BPS recorded that there are 1.49 million tourists who came to Java via Soekarno-Hatta Airport. 
TABLE II. TOURIST ARrIVALS TO TANJUNG LESUNG 2015

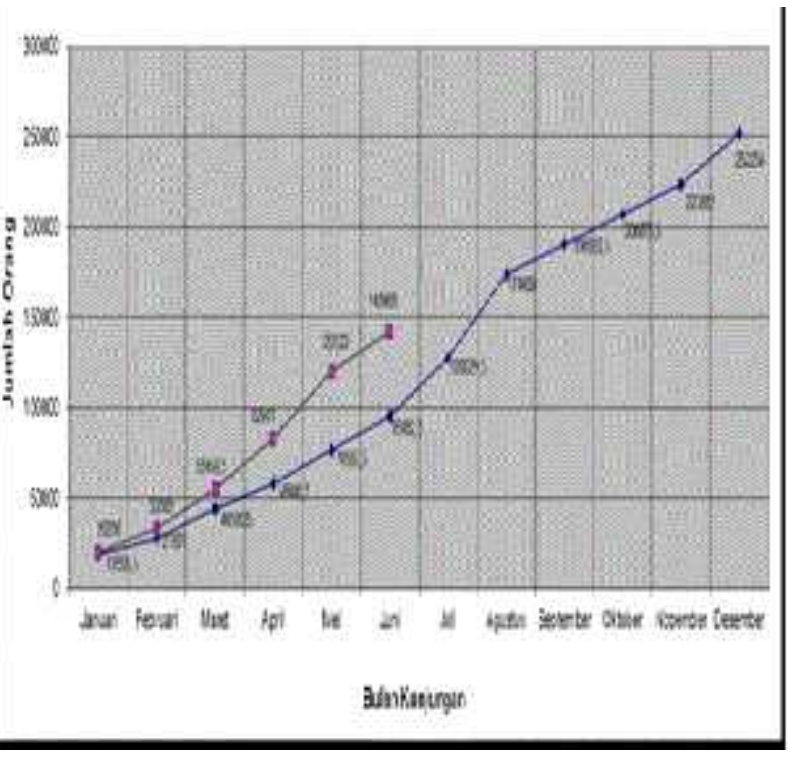

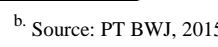

\section{B. Tourism Development}

Tourism development has a very important meaning in terms of various aspects. From the economic side of tourism, in recent years the tourism sector contributes to GDP, (either through foreign exchange and economic turnover), can open up business opportunities of tourism services (either directly or indirectly), and job opportunities very much.

In establishing the pillars of tourism development aims: 1. Improving economic growth, 2. Improving the welfare of the people, 3. Eradicating poverty, 4. Overcoming unemployment, 5. Preserving nature, environment and resources, 6. Promotion of culture, 7. Raising the image nation, 8. Cultivate love for the homeland, 9. Strengthen the identity and unity of the nation, 10. Deepen friendship among nations.

\section{Marketing Management}

In general, marketing management can be defined as an art and a science to be able to choose the target market, and acquire, retain, and grow customers through the creation, delivery and communication of superior value to the customer (Kolter and Keller, 2009). Marketing strategies that can be made include the development of places and activities of travel, accommodation, access to tourist destinations, means of supporting tourism, and also tourism marketing communication effective and efficient.

The basic concept of marketing communication (4P) is: 1. Product (Product) 2. Price (Price) 3. Place (Points, Distribution) 4. Promotion (Promotion). Developing Effective Marketing Communication there are eight (8) steps in developing communication and promotion program totally effective. Communicators marketing must: 1. Identify the intended audience of the communication objectives 2 . Determind 3. Design 4. Choose message communication channels 5. Determind total budget of sale 6. Establish a decision on the promotion mix (Marketing Mix) 7. Measure results of these promotions 8. Manage and coordinate the process of integrated marketing communications.

Mix Marketing Communications consists of Communication Top 5 ways: 1.Advertising All forms of nonpersonal presentation and promotion of ideas, goods or services paid for by a particular sponsor. Sales 2.Promotion Various short-term incentives to encourage the desire to try or buy a product or service. 3.Relationship society and Publicity Various programs to promote or protect the image of the company or individual products. 4.Selling personally direct interaction with one or more prospective buyers to make a presentation, answer questions, and receive orders. 5.Marketing direct use of mail, telephone, facsimile, e-mail, and other nonpersonal interfaces to directly communicate with or to get direct feedback from certain customers and prospective customers.

Likewise with Banten province incentive to introduce to various cities in cooperation with the Culture and Tourism promotion are:

1) Participation event tourism and creative economy national scale

2) Promotion of the regional event participation

3) Banten Beach Festival

4) Promotion in print media

5) Campaign in online media

6) Promotion on radio

7) Campaign on television

8) Enrichment content and user interaction site tourism promotion

9) Strengthening featured promotions district municipality

10) Market dialog / travel dialog

11) Operator familiar trip

12) Banten Tourism Week

13) Anyer Panarukan Festival

14) Tanjung Lesung Festival

\section{Branding}

Branding is a set of processes and activities to create a brand. (Kotler and Keller, 2009) defines branding as an effort to include a product or service with the power of a brand. According to them, a brand is a 'perceptual entity that is rooted in reality, but it reflects the perceptions and even thoughts and feelings'. Branding efforts can be done in many ways, but the common practice is to specify a brand personality, brand positioning, and brand identifiers.

Brand is defined as the area of marketing activities to promote the positive image of a tourist destination for the sake of influencing the consumer's decision to visit (Blain, et al., 2005).

\section{E. City Branding}

According to Simon Anholt in Moilanen and Rainisto (2009: 7), City Branding is the image of a destination management through strategic innovation and coordination of economic, social, commercial, cultural, and government 
regulations. City branding is a tremendous magnitude to develop the city as well hook and foreign investment.

Many factors play an important role in order to foster the perception that will set in a new image of Banten Province. Which is ultimately expected to be applied by the Banten Province as a worthwhile investment.

According Tjiptono (2005: 49) brand image or brand description is the description of the association and the confidence of consumers towards a particular brand.

Branding efforts can be done in many ways, the tourism marketing strategy has three (3) ways: 1 . Brand Personality 2. Brand Positioning 3. Brand Indentifiers (Gelder 2005).

\section{F. Branding Personality}

Brand personality is a specific mix of human nature possessed by a product or service. Research shows that the brand has a personality to be preferred by consumers because people tend to choose a brand that has a personality that matches their personality.

Determining strategy brand identity is a very important strategic initiative. Brand personality has six elements, among others: 1. Ritual (associated with certain events) 2. Simbol (the image is considered to have a value-added) 3 . Heritage of Good (the specific advantages) 4.The aloof snob (city rand rating indicates characters) 5 . The belongging (city brand to make tourists feel part of a large group) 6. Legenda (history)

Brand personality of Banten Province meets six elements. They are the elements that make the city increasingly strong brand of Banten Province which include the elements of rituals, symbols, heritage of good and legends, this is because the city brand used Banten Province raised the potential residing in these elements.

\section{G. Branding Positioning}

Positioning is a concept for placing products on the market that are based on the perceptions and preferences of consumers for a product. Positioning concept originated from the structure of the market, the company's competitive position, and product concepts of substitution and competition among similar products. Positioning is often used to define or describe the image of a product compared with the products of its competitors.

There are several definitions of positioning, such as Kasali (2003: 506), define positioning as follows: "Positioning is not what you do to a product. It is what you do to the mind of the prospect", it means that positioning is not something done on the product, but something that is done to the brain prospect. Positioning is not a product strategy, but a communication strategy. Positioning relates to how consumers are placing products in the brain, in the realm of imagination, so that potential consumers have a 11 certain votes and identify themselves with the product.

There are several elements of Brand Positioning namely: 1. Determine Positioning: a. Positioning city brand (which is preferred and is considered important in the eyes of tourists) $b$. Unlike competitors Unieqly \& c. Excess product; 2.
Communicating Positioning: a. Be creative b. Simplicity c. Own, Dominate, Protect d. Use Their Language.

\section{H. Branding Identifiers}

Brand identifier can be classified into three groups: elements of the brand itself (name, logo, symbols, characters, slogans, jingles, signs / signage, a spokesman for the brand / spokesperson), products (services and all marketing activities and marketing program support), and other associations whose meaning associated with the brand (a person, a place, or an event / specific experience).

Brand identifiers of Banten Province with positioning elements, verbal, visual, experiential capable of distinguishing the products offered in each city. Elements of verbal, visual created to represent the brand personality for travelers then be able to understand the character of the city through verbal and visual. But the experiential element is still weak due to the lack of bids in Banten Province tourism products so that tourists who visit in Banten Province in each region is relatively short deadline and less.

Department of Culture and Tourism Banten Province realizes that the target market is a very important part of the marketing strategy.

The target market is the focus in the development of tourism marketing is the Southeast Asian market. By making the Southeast Asia as the main target market of Banten Province tourism due on the consideration of the region is the largest tourist contributor for a visit to the Province of Banten.

\section{Brand Image}

Brand is expected to be a guarantee that the area that bears the brand will be able to offer anything as promised to the traveler / visitor community. Of course, the goal of all efforts to build a brand is to make the area more and more known among the wider public and tourists around the world, which in turn results in increased positive behavior of visitors and ultimately the welfare of local communities.

There are several important agendas that need to be answered related trend areas that bring the brand through attractive tagline. The question is, can the brand image promoted travelers to arrest and can the brand influence positive behavior of visitors.

Kotler (2006) states that the buyer / user may have different responses to the company's image / point. Kotler (2006) asserts that the brand image is the confidence of the brand. In this case the brand image is the public perception that he was trust the company of the products / services offered. Brand image is the image of a brand that is regarded as a group of associates who connect consumer thinking toward a brand name (Biel, 1992 in Huh, 2006). In order to function, the image of the brand must be delivered through various means of communication available and brand contact. Keller (1998) suggests that a positive brand image created by an association of strong brands, unique and good. Furthermore Keller (1998) also confirms that the brand image built from brand association is usually associated with the information in the memory with something related to the service / product / related places. 
This study adopts some items which include both cognitive and affective imagery. The image of a tourist destination determines a fundamental role in the success of a tourist destination. Perceptions on the image of a tourist destination influencing satisfaction and intention to visit locations associated in the future.

\section{CONCLUSION}

Business tourism is included in the form of intangible services. One of the characteristics of services in the form of intangibility aspect that makes the consumer needs to get information or signaling convincing before deciding to buy it. Brand is one form of signal that is widely used to deliver a product / service and even become a powerful weapon to convince users or potential users to buy it.

Tourism as a form of services identical to the image, so the image of the brand should be able to develop in a positive direction. By having a positive image rating would be expected to build a positive perception and make the decision to visit. While that has ever been will be keen to visit again and recommend to others. From the results of studies showing that the brand image of Banten Province has not been optimally recognized by visitors from outside the Province of Banten, the findings need to be addressed by the use of marketing communication strategy more focused, target of achieving a clear and consistent and involve all stakeholders in the tourism area.

Branding efforts can be done in many ways, the tourism marketing strategy has three (3) ways: 1 . Brand Personality 2. Brand Positioning 3. Brand indentifiers (Gelder 2005).

\section{REFERENCE}

Anholt, S. 2005. Anholt Nation Brands Index: How does the world see America?. Journal of Advertising Research, September, pp 296-304.

Blain, C., S., Levy, \& JRB. Ritchie, 2005. Destination branding: Insights and Practices from destination management organization. Journal of Travel Research Vol. 43, No. 4, pp. 328-338.

Cravens, D.W. and N.F. Piercy. 2006. Strategic Marketing, (8th ed.). NY: Mc Graw Hill

Gelder, Sicco van. 2005. Global Brand Strategy: Unlocking Branding Potential Across. Countries, Cultures \& Markets. PT Gramedia Pustaka Utama. Jakarta.

Huh, J. 2006. Destination branding as an informational signal and its influence on satisfaction and loyalty in the leisure tourism market. Published PhD Dissertation. Faculty of the Virginia Polytechnic Institute and State University.

Kasali, R. 2003. Manajemen Public Relations. Grafiti, Jakarta. Keller, L.L. 1998. Strategic Brand Management: Building, Measuring, and Managing Brand Equity. NJ: Prentice Hall.

Keller, L.L. 2003. Brand synthesis: The Multidimensionality of Brand Knowledge. Journal of Consumer Research. Vol. 29, No. 4, pp. 595-600.

Kotler, P. and K.L. Keller. 2009. Marketing Management, (13th ed.). Upper Saddle River, NJ: Prentice Hall

Kotler, P. 2006. Marketing Management, Millennium edition. NJ: Prentice Hall.

Moilanen, Teemu \& Rainisto. 2009. How to Brand Nations, Cities and Destinations, A Planning Book for Place Branding. USA: Palgrave Macmillan.

Tjiptono, Fandi. 2005. Brand Management \& Strategy. Malang: Bayu Media Publishing. 